\title{
Re-Evaluation Curriculum and Implementation: A Case Study in MTsS PTP-VI Berangir
}

\author{
Muhammad Munawir Pohan \\ Department of Management, Faculty of Economics, University of Al Washliyah Labuhanbatu, Sumatera Utara, \\ 21412, Indonesia \\ munawwarohp@yahoo.com \\ *Corresponding Author: munawwarohp@yahoo.com | Phone : +6281263898919
}

Received: 28 July 2020

Revised: 26 August 2020

Accepted: 23 September 2020

\begin{abstract}
This study aims to evaluation of implementation the 2013 Curriculum in MTsS PTP-VI Berangir which includes (1) readiness for implementation; (2) learning process and learning evaluation, (3) results of implementation; and (4) level of successful implementation. The method used in this study is the method of evaluating the Countenan Stake model which divides the curriculum components in the observation matrix and the consideration matrix including the antecedent, process (transaction), and results (outcomes) stages. The study was conducted at MTsS PTP-VI Berangir, North Labuhanbatu Regency, North Sumatra Province which is a private school. The results showed that the preliminary stage or readiness for implementation included the readiness of teachers, books, infrastructure, and lesson plans very well $(90 \%)$, the stage of the process which included learning activities and learning evaluation was very good $(97 \%)$, and the results of implementation which included responses students and learning outcomes are also very good (95\%). The implementation of the 2013 Curriculum in MTsS PTP-VI Berangir can run very well with the support of meeting national education standards and teachers who have good motivation, creativity and performance.
\end{abstract}

Keywords: Evaluation; Curriculum; Implementation;

\section{Introduction}

The curriculum is one of the instrumental inputs in achieving national education goals. In achieving these objectives the curriculum is dynamic and always experiences change and development (Mulyasa, 2013: 43). The curriculum development process began since the 1964 curriculum, the 1968 curriculum, the 1975 curriculum, the 1984 curriculum, the 1994 curriculum, in 2004 the Competency Based Curriculum (KBK) was implemented, in 2006 the Education Unit Level Curriculum was implemented, until 2013 the implementation of the 2013 Curriculum was implemented. simultaneously implemented in 2014.

In the historical period of the transformation of education in Indonesia, the curriculum has always been a serious conversation among academics, politicians, and even the laity despite the unclear orientation of the curriculum implementation. A curriculum that is supposed to be a means to achieve the expected education target will not be meaningful if it is not supported by the necessary facilities such as qualified teaching staff, validity of sources/teaching materials, appropriate methodology, and clear orientation of the objectives to be achieved. The 2013 curriculum is the latest curriculum that emphasizes the use of scientific approaches, authentic assessment and thematic integrative in learning. This curriculum is expected to be able to produce a critical and creative generation of Indonesia in accordance with the demands of the times. Education with a scientific approach has the potential to lay an important foundation for children's knowledge and interest in science (Gerde, H. K, 2013: 317). The attitude domain consists of accepting, implementing, appreciating, living, and practicing. The domain of knowledge consists of remembering, understanding, applying, analyzing, evaluating, and creating. The domain of skills consists of interpreting, producing, editing, abstracting, and converting (Pohan, 2019:335).

The 2013 curriculum is designed to prepare students with various competencies. The competencies needed to respond to these global challenges include: communication skills, good moral attitude, critical thinking skills, ability to be good citizens, ability to live in the midst of global society, ability to tolerate different views, have readiness to work, has intelligence in accordance with his talents, has a sense of responsibility towards the environment, and has a broad interest in life. 
At the beginning of implementation, the 2013 Curriculum raised a lot of criticism and protest because it was considered to cause problems. Implementation of the 2013 curriculum still faces one major obstacle that must be addressed, namely the issue of teacher readiness as the key to successful implementation. (Alawiyah, 2014: 58). Other implementation problems according to (Ahmad, 2014: 101) are the content and packaging of the curriculum, teacher readiness, and the emergence of multiple interpretations in their implementation. Hapsari (2015:23) in his research found that the ability of teachers in developing, implementing, and evaluating the 2013 curriculum was quite good.

The emergence of various problems in the implementation of the 2013 curriculum did not dampen the enthusiasm of a number of schools that still wanted to implement it, even those schools had the courage to do it independently. Problems encountered at the beginning of curriculum implementation are reasonable, both in schools with public status and private schools. However, these problems should be explored in depth to immediately find the best solution in order to achieve the goals expected from the curriculum itself.

\section{Methods}

The Curriculum evaluation is the activity of gathering information about a curriculum to give consideration to perfection and decision making (Norris, 1998: 79). Meanwhile, according to (Hasan, 2014: 35), curriculum evaluation as a systematic effort to collect information about a curriculum that is used as material for consideration about the value and meaning of the curriculum in a particular context.

The implementation of the curriculum is as the operationalization of curriculum concepts that are still potential (written) to be actual in the form of learning activities (Majid and Rochman, 2014: 112). Meanwhile according to (Rusman, 2012: 62), learning in the classroom becomes a place to implement and test the curriculum. In learning activities, the curriculum concept will be manifested real. The above description shows the need for evaluation research on the implementation of the 2013 curriculum in secondary schools. This study aims to obtain information about the readiness, implementation, and results of curriculum implementation. Implementation readiness includes the readiness of books, teachers, infrastructure, and the condition of the lesson plan. Implementation includes the learning process and evaluation. The results of the implementation include the responses of students and the acquisition of learning outcomes.

This evaluation research was conducted at MTsS PTP-VI Berangir, North Labuhanbatu District, North Sumatra Province. The evaluation model used is Countanance Stake. This model divides the evaluation activities into an observation matrix and a consideration matrix at the antecedent, transaction (outcome), and outcome stages. (Sanders, JR, Worthen, B.R., \& Fitzpatrick, J.L, 1973) in Noviatmi, 2015: 157).

The results of observations are compared with the standards, in this case the National Education Standards used in the implementation of the 2013 Curriculum. Consideration is given to the components that show gaps between the results of observations and standards. Data obtained from interviews and observations. Interviews with principals and teachers were conducted using interview guides to obtain information about teacher readiness and books. While observations were made using validated instruments to determine the condition of infrastructure, RPP documents, learning processes, assessment documents, and students' responses in learning. Interview data were analyzed using qualitative descriptive methods, while observational data were analyzed using quantitative descriptive methods with predetermined criteria.

\section{Results and Discussions}

The results of curriculum evaluation using the Countenan Stake model show the results as illustrated in the table 1.

Table 1. Evaluation Results Data for the Implementation of 2013 Curriculum in MTsS PTP-VI Berangir

\begin{tabular}{|c|c|c|c|}
\hline Stages & Aspect & Intents & Percentage $(\%)$ \\
\hline Preliminary & Teacher's Condition & Has attended the 2013 Curriculum training & 70 \\
\hline \multirow[t]{3}{*}{ (Antecedent) } & Book Conditions & Meet the number of students and teachers & 100 \\
\hline & condition of infrastructure & Meet the standards of infrastructure & 92 \\
\hline & RPP conditions & Meet process standards & 100 \\
\hline Process & Learning & Meet process standards & 95 \\
\hline (Transaction) & Evaluation & Meet the assessment standards & 100 \\
\hline Results & Student Response & Active \& uplifting & 90 \\
\hline (Outcomes) & Learning outcomes & Achieve KKM & 100 \\
\hline
\end{tabular}




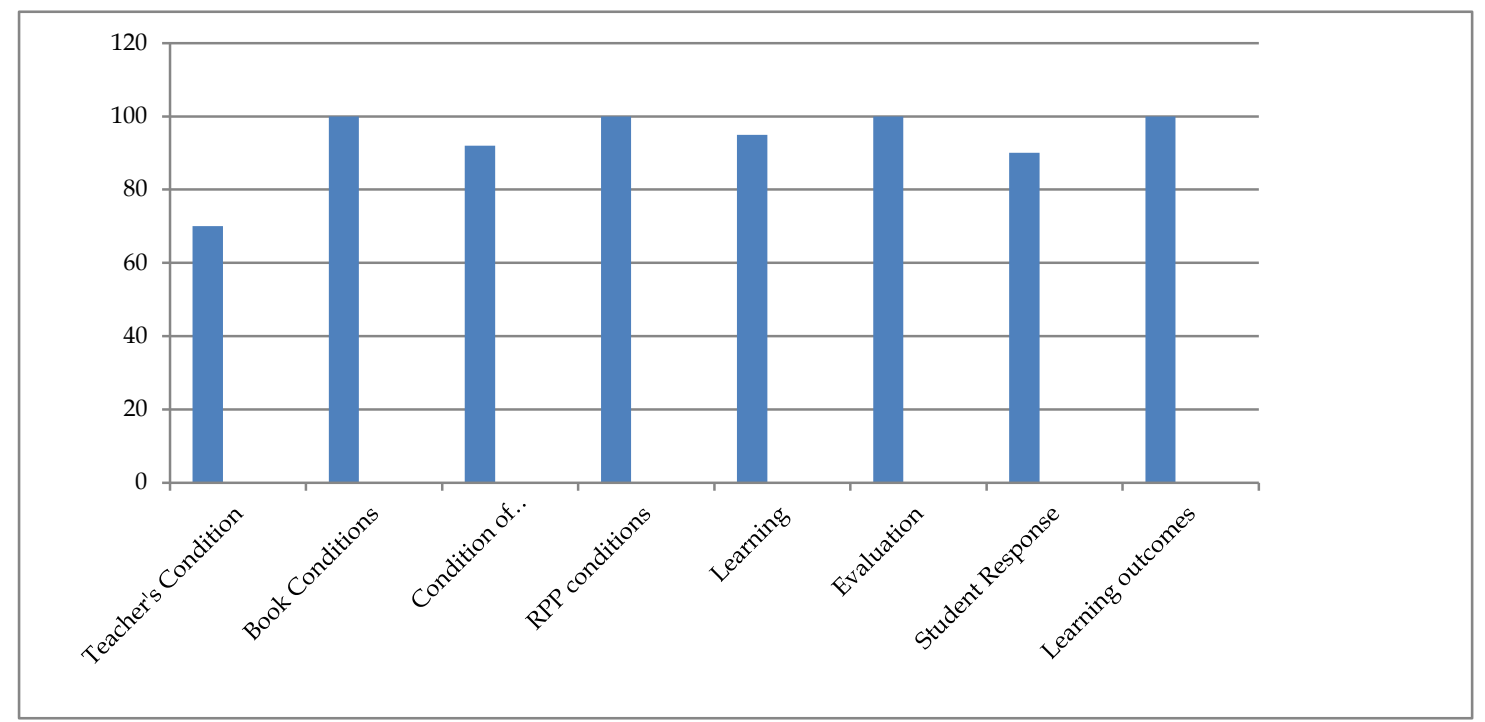

Figure 1. Diagram for the Implementation of 2013 Curriculum in MTsS PTP-VI Berangir

Table 1 is the evaluation result data for the implementation of 2013 Curriculum in MTs S PTP-VI Berangir. At the antecedent stage it shows that $70 \%$ of teachers have attended the 2013 Curriculum training; books $95 \%$ have met the number of students and teachers; the condition of infrastructure $92 \%$ meets the standards of infrastructure; and the condition of the RPP is 100\% according to the process standard. At the transaction stage, learning is in accordance with the standard process of $95 \%$ and evaluation of learning is in accordance with the assessment standard of $100 \%$. In the outcomes phase, $90 \%$ of the classes are observed, students give a positive response to learning and all students $(100 \%)$ obtain learning outcomes above the minimum completeness.

The three stages evaluated are antecedents, transactions, and outcomes when compared to the criteria table showing very good results. However, it has not shown a success rate of $100 \%$ so that it needs to be given considerations that are useful for further improvement of curriculum implementation. Book Readiness. Books as one of the curriculum documents have an important role in learning. In the 2013 curriculum, the student book and the teacher's hand are even one of the elements that has experienced many changes. If in the previous curriculum there were no student books or teacher guides available, then in the 2013 Curriculum the government tried to provide student books and teacher handbooks so that the essence of curriculum change could be realized in learning.

The results of interviews with the principal produce information that the school has provided student books in accordance with the number of students and teacher books in accordance with the number of teachers. This information is evidenced by observations in the class which show that when learning all students have used curriculum book, so also the teachers have used the teacher's handbook in preparing learning plans. Thus the readiness of the book is $100 \%$ fulfilled. Even though nationally the procurement of curriculum books has constraints, MTsS PTP-VI Berangir can overcome them by making a number of breakthroughs, such as in the first year when schools implementing Curriculum had not received books from the government, MTsS PTP-VI Berangir printed its own curriculum book from soft file provided by the Ministry of Education and Culture.

At the time of observation, most of the teachers opened learning with apperepi, motivated and demonstrated something using LCD displays, images, and real objects. In the use of learning resources or media, most teachers also demonstrate their skills in using learning resources and learning media. In addition, most teachers use LCD projector media to display images, videos, and writing. This shows the teachers have skills in information technology. Teachers and students have begun to get used to carrying out the stages of scientific learning such as observing, asking questions, gathering information, reasoning or analyzing, and communicating. However, not all stages in the scientific approach are carried out to the fullest, especially at the stages of asking, analyzing and communicating. Seeing the results of the evaluation of the excellent implementation in the preliminary stage, the process and the results amidst the obstacles encountered, it appears that the teachers at MTsS PTP-VI Berangir have strong motivation and good competence in implementing the 2013 Curriculum. Strong motivation makes teachers have good performance that is able to perform various tasks in earnest even though it is considered burdensome. Their motivation has also encouraged the creativity of the teachers so that they can make various efforts in completing assignments and overcome obstacles encountered. 


\section{Conclusion}

The results of this study conclude a number of things: (1) readiness for implementation in MTsS PTP-VI Berangir is windy in terms of the teacher, student book and teacher's handbook, infrastructure, learning plans categorized very well (90\%); (2) the learning process and learning evaluation categorized as very good (97\%) are in accordance with the Process Standard and the Educational Assessment Standards; (3) the results of implementation which include the responses of students in learning and learning outcomes can be described in numbers (95\%) and categorized very well; (4) the success rate of implementation is included in the very good category (94\%); (5) the successful implementation of this excellent curriculum cannot be separated from the fulfillment of national standards of education, motivation, creativity and good performance of the teachers as curriculum implementers.

Based on these results, the implementation of the 2013 Curriculum in schools needs to begin with the fulfillment of the National Education Standards. For this reason, in order to implement the 2013 Curriculum in all government schools, it is necessary to continue to push for the fulfillment of National Standards in all schools.

\section{References}

Ahmad, S. (2014). Problematika Kurikulum 2013 \& Kepemimpinan Instruksional Kepala Sekolah. Jurnal Pencerahan, 8(2): 98-108. Tersedia (http://www.jurnal.unsyiah.ac.id/JPP/article/view/2158).

Alawiyah, F. (2014). Kesiapan Guru dalam Implementasi Kurikulum 2013. Info Singkat, VI(15): 9-12 / I. P3DI /Agustus/2014.

Gerde, H.K. (2013). Using the Scientific Method to Guide Learning: an Integrated Approach to Early Childhood Curriclum. Early Childhood Education Journal, 41(5): 315-323. Tersedia (https://link.springer.com/article/10.1007\%2Fs10643-013-0579-4).

Hapsari, D.Y. (2015). Kemampuan Rata-rata Guru dalam Mengembangkan, Mengimplementasikan dan Mengevaluasi Kurikulum 2013. Indonesia Journal of Curriculum and Educational Technology Studies, 3(1): 22-28.Tersedia(https://journal.unnes.ac.id/sju/index.php/jktp/article/view/8680).

Hasan, H., S. (2014). Evaluasi Kurikulum. Bandung: Remaja Rosdakarya.

Majid, A \& Rochman. C. (2014). Pendekatan Ilmiah dalam Implementasi Kurikulum 2013. Bandung: Remaja Rosda Karya.

Mulyasa, H.E. (2015b). Guru dalam Implementasi Kurikulum 2013. Bandung: Remaja Rosdakarya.

Norris, N. (1998). Curriclum Evaluation Revisited. Cambridge Journal of Education, 28(2): 207-183. Tersedia (https://www.tandfonline.com/doi/abs/10.1080/0305764980280206).

Pohan, J., E. (2019). The Development of Inquiry Learning Model on Indonesian Language Lessons. International Journal for Educational and Vocational Studies. Tersedia (DOI: https://doi.org/10.29103/ijevs.v1i4.1464).

Rusman. (2012). Manajemen Kurikulum. Jakarta: Rajagrafindo Persada.

Sanders, J.R. (2011). Program Evaluation: Alternative Approaches and Practical Guidelines. Boston: Pearson Education, Inc. 